\title{
Antimicrobial Effects of Laser-assisted Photodynamic Therapy in Pediatric Endodontic Treatment: A New Clinical Horizon
}

\author{
AR Prabhakar, Chandrashekar Yavagal, Sonali Agarwal, N Basappa
}

\begin{abstract}
Aim: The purpose of this study was to compare disinfection of deciduous root canal by conventional chemomechanical debridement (CMD) with sodium hypochlorite $(0.5 \%)$ vs laserassisted photodynamic therapy (PDT).

Materials and methods: Twelve children aged 4 to 7 years with informed consent from their parents were studied. Access cavities were prepared and culture samples were taken before the commencement of the therapy, after CMD using $0.5 \%$ sodium hypochlorite and after laser-assisted PDT using methylene blue (MB) dye. Samples were taken by placing a sterile paper cone into the canals and transferring them into brain heart infusion broth. The samples were then subjected for microbiological processing so as to count the total number of viable bacteria.
\end{abstract}

Results: Laser-treated canals showed a reduction in bacterial load by $99.99 \%$ as against $83.9 \%$ obtained after the use of conventional CMD with sodium hypochlorite.

Conclusion: Laser-assisted PDT can be used as an excellent adjunct to CMD to obtain near perfect disinfection of deciduous root canals.

Keywords: Laser-assisted photodynamic therapy, Conventional chemomechanical debridement, Pediatric endodontics.

How to cite this article: Prabhakar AR, Yavagal C, Agarwal S, Basappa N. Antimicrobial Effects of Laser-assisted Photodynamic Therapy in Pediatric Endodontic Treatment: A New Clinical Horizon. Int J Laser Dent 2013;3(3):77-81.

\section{Source of support: Nil}

Conflict of interest: None declared

\section{INTRODUCTION}

The advent of laser therapy has opened new vistas for faster, more effective and less painful dental procedures proving to be useful in children. It is fast gaining popularity and it has revolutionized the treatment in restorative and surgical dentistry. The endodontic treatment of deciduous teeth is another area where it is of fast gaining importance. In the endodontic treatment of deciduous teeth, laser therapy holds special significance as it not only maintains the health of the teeth and supporting tissues but also the integrity of the dental arch until its normal exfoliation.

The endodontic treatment of deciduous teeth is extremely challenging and the ultimate success depends upon achieving maximally sterile root canals before obturation, which is virtually impossible with just instrumentation and irrigation. ${ }^{1}$ The anatomical complexities of the deciduous root canals-accessory foramina in the apical and furcal areas, ever persistent root resorption, in conjunction with the behavioral difficulties faced by the clinician due to children's lower tolerance toward longer treatments, as well as their overall compliance makes it imperative that pediatric operative procedures continuously evolve and metamorphose not only on the technical front but on the ergonomic front as well. ${ }^{2}$ In such a scenario photodynamic therapy (PDT)-a laser based therapy, seems to be a promising addition to achieve sterilization in the infected root canals of deciduous teeth.

The use of PDT for inactivation of microorganisms was first demonstrated more than 100 years ago, when Oscar Raab reported the lethal effect of acridine hydrochloride on Paramecia caudatum. Photodynamic therapy (PDT) is based on the concept that nontoxic photosensitizers can be preferentially localized in certain tissues and subsequently activated by light of the appropriate wavelength to generate singlet oxygen and free radicals that are cytotoxic to cells of the target tissue. ${ }^{3}$ Therefore, the objective of the present study was to evaluate the antimicrobial effects of methylene blue (MB)-mediated PDT in deciduous root canals with pulpal necrosis. This is an in vivo study.

\section{MATERIALS AND METHODS}

Twelve children of both genders aged 4 to 7 years with necrotic pulps of deciduous teeth, were studied at the Department of Pedodontics and Preventive Dentistry, Bapuji Dental College and Hospital, Davangere, Karnataka, India.

An informed consent was taken from parents or legal guardians in all children and the study has been approved by the institutional ethical committee.

The inclusion criteria for the cases were as follows:

1. Necrotic carious lesions of deciduous teeth affecting the pulp evidenced by an intraoral periapical radiograph.

2. Children should not have been undergoing any medical treatment and should not have received antibiotics in last 3 months.

The exclusion criteria were as follows:

1. Necrotic pulps in the teeth, with a radiolucent area in the furcation affecting the permanent successor teeth and recommended for exodontics.

2. Deciduous teeth with radicular resorption of more than half of the total root length. 


\section{CLINICAL PROCEDURE AND CULTURE}

The root length was measured with a millimeter ruler on an intraoral periapical radiograph, and the working length for chemomechanical debridement determined. After anesthesia with lidocaine (Lignox 2\%, Mumbai, India) and rubber dam isolation (Ash, Dentsply, UK), the carious tissue and the roof of the pulp chamber was removed with a spherical rotary bur no. 2 at high rotation. Endodontic access was achieved and the radicular canals of each deciduous molar received a sterile paper cone with an anatomic diameter compatible to the canal for 30 seconds. The first samples were then immediately placed in brain heart infusion (BHI). Thereafter, the chemomechanical debridement (CMD) was performed with Kerr files (MANI, Japan), with anatomic diameter compatible to the radicular canal, together with $0.5 \%$ sodium hypochlorite irrigation (SDFCL, Fine-Chem Ltd, Mumbai, India) after which the sample was obtained for culture as previously. Thereafter, the access cavity was filled with MB dye solution (concentration $50 \mu \mathrm{g} / \mathrm{ml}$ or 134 $\mathrm{mM}$ ) prepared by dissolving MB dye (Vanshi Chemicals, Mumbai, India) in sterile phosphate buffered saline (Loba Chemie Laboratory Reagents, Mumbai, India) and the entire solution was filter sterilized before use. The dye solution was placed in the coronal portion of the access cavity using a sterile disposable syringe and was allowed to remain within the cavity for 5 minutes followed by laser light from $36 \mathrm{~mW} / 660 \mathrm{~nm}$ diode laser (Silberbauer Low Level Laser, Austria) (Fig. 1), applied for 4 minutes at an energy fluence of $8.6 \mathrm{~J} / \mathrm{cm}^{2}$, keeping the tip of the laser unit on the crown of the tooth (Fig. 2). After conclusion of the PDT, culture studies were again performed from the radicular canals of each deciduous tooth in the same manner as described above.

\section{MICROBIOLOGICAL PROCESSING}

All samples (before CMD, after CMD and after laser application) were cultivated so that we could detect the total number of viable bacteria.

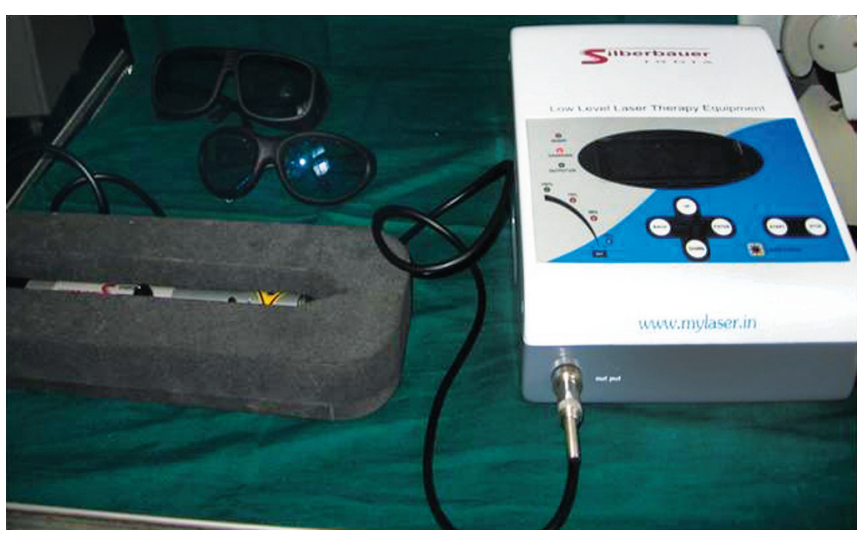

Fig. 1: Low level diode laser $660 \mathrm{~nm}$ (Silberbauer, Austria) used

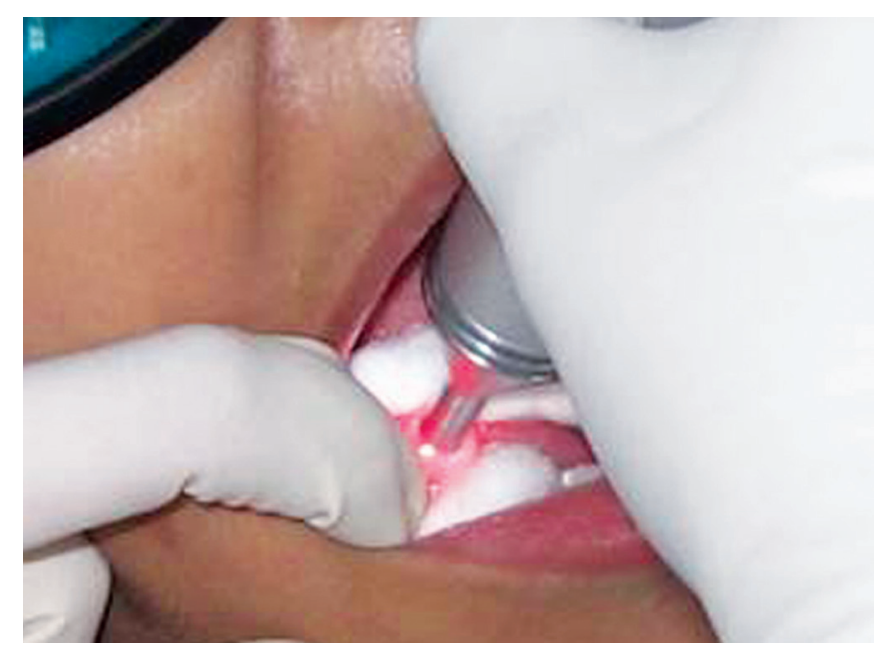

Fig. 2: Photodynamic therapy being performed in one of our patients

The samples taken for culture were homogenized in a tube shaker (Vortex-Cole-Parmer, India) for 3 minutes. Then $25 \mu \mathrm{l}$ aliquot of the solution was seeded on plate surface containing blood agar with a micropipette. ${ }^{4}$

The plates were then incubated for 5 days at $37^{\circ} \mathrm{C}$ in $85 \%$ nitrogen $\left(\mathrm{N}_{2}\right), 10 \%$ carbon dioxide $\left(\mathrm{CO}_{2}\right)$ and $5 \%$ hydrogen $\left(\mathrm{H}_{2}\right)$ atmosphere. After 5 days the total number of viable bacteria unit-forming colonies (ufc) was determined in each sample, i.e. before CMD after CMD and after PDT treatments. Statistical significance was determined by Wilcoxon test.

\section{RESULTS}

The ufc/ml before CMD, after CMD and after PDT in each case and the mean reduction in our cases is shown in Tables 1 and 2. The mean reduction in ufc after CMD was 1,381-552.7 ufc/ml (83.9\% reduction). After PDT the mean reduction was 1,637.4-635 ufc/ml (99.99\% reduction). This difference was highly statistically significant $(\mathrm{p}=0.002)$. The findings were similar in all the cases. The mean total viable microbes counts-before CMD, post-CMD and after PDT in the cases are shown in Graph 1 whereas the mean percentage reduction in viable microbial count-after CMD and after PDT is shown in Graph 2.

\section{DISCUSSION}

Success of endodontic treatment depends on the ability to obtain a maximally sterile root canal before obturation. ${ }^{2}$ Literature reports that endodontic therapy will have a $94 \%$ success rate when a negative microbiological culture is obtained from the root canal at the time of obturation which is reduced to $68 \%$ in case cultures are positive. ${ }^{5,6}$

The anatomical complexity of the deciduous root canal system with its isthmuses, ramifications, make complete debridement of bacteria almost impossible, even when 
Table 1: Total viable microbiological count (ufc/ml) before chemomechanical debridement, post-CMD and post-PDT and the reduction in the total viable microbial count observed with these treatments in each case

\begin{tabular}{|c|c|c|c|c|c|c|c|}
\hline Patient & $\begin{array}{l}\text { Before CMD (x) } \\
\quad(u f c / m l)\end{array}$ & $\begin{array}{l}\text { Post-CMD }\left(x_{1}\right) \\
\quad(u f c / m l)\end{array}$ & $\begin{array}{c}\text { Difference } \\
\left(x-x_{1}\right)\end{array}$ & $\begin{array}{l}\text { Reduction (\%) } \\
\left(x-x_{1}\right)\end{array}$ & $\begin{array}{c}\text { Post- } \\
\text { photodynamic } \\
\text { therapy }\left(x_{2}\right) \\
\text { (ufc/ml) }\end{array}$ & $\begin{array}{c}\text { Difference } \\
\quad\left(x-x_{2}\right)\end{array}$ & $\begin{array}{l}\text { Reduction (\%) } \\
\left(x-x_{2}\right)\end{array}$ \\
\hline 1. & 2280 & 342 & 1938 & 85 & 0 & 2280 & 100.0 \\
\hline 2. & 2160 & 324 & 1836 & 85 & 0 & 2160 & 100.0 \\
\hline 3. & 1860 & 372 & 1488 & 80 & 0 & 1860 & 100.0 \\
\hline 4. & 1800 & 324 & 1476 & 82 & 0 & 1800 & 100.0 \\
\hline 5. & 2100 & 210 & 1890 & 90 & 0 & 2100 & 100.0 \\
\hline 6. & 520 & 104 & 416 & 80 & 0 & 520 & 100.0 \\
\hline 7. & 480 & 72 & 408 & 85 & 0 & 480 & 100.0 \\
\hline 8. & 1500 & 300 & 1200 & 80 & 0 & 1500 & 100.0 \\
\hline 9. & 1870 & 280 & 1590 & 85 & 1 & 1869 & 99.9 \\
\hline 10. & 2100 & 294 & 1806 & 86 & 0 & 2100 & 100.0 \\
\hline 11. & 2010 & 301 & 1709 & 85 & 0 & 2010 & 100.0 \\
\hline 12. & 970 & 155 & 815 & 84 & 0 & 970 & 100.0 \\
\hline
\end{tabular}

Table 2: Mean viable microbiological counts before and after chemomechanical debridement and after photodynamic therapy in our cases

\begin{tabular}{|c|c|c|c|c|c|c|c|}
\hline & $\begin{array}{l}\text { Before } C M D(x) \\
\quad(u f c / m l)\end{array}$ & $\begin{array}{c}\text { Post-CMD (x1) } \\
\text { (ufc/ml) }\end{array}$ & $\begin{array}{l}\text { Difference } \\
\quad\left(x-x_{1}\right)\end{array}$ & $\begin{array}{l}\text { Percentage of } \\
\text { Reduction } \\
\left(x-x_{1}\right)\end{array}$ & $\begin{array}{c}\text { After } \\
\text { photodynamic } \\
\text { therapy }\left(x_{2}\right) \\
\text { (ufc/ml) }\end{array}$ & $\begin{array}{l}\text { Difference } \\
\quad\left(x-x_{2}\right)\end{array}$ & $\begin{array}{l}\text { Percentage of } \\
\text { reduction }\left(x-x_{2}\right)\end{array}$ \\
\hline Mean & 1637.5 & 256.5 & 1381.0 & 83.9 & 0.1 & 1637.4 & 99.99 \\
\hline SD & 635.0 & 97.9 & 552.7 & 3.0 & 0.3 & 635.0 & 0.02 \\
\hline Z-value & - & - & 3.05 & - & - & 3.06 & - \\
\hline$p$-value & - & - & $0.002^{*}$ & - & - & $0.002^{*}$ & - \\
\hline
\end{tabular}

*Statistically significant results

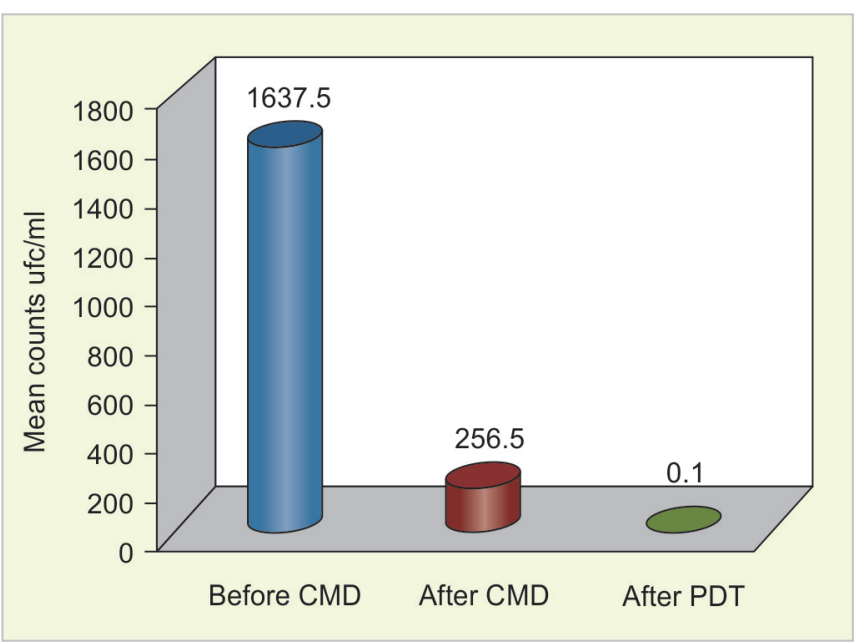

Graph 1: The mean total viable microbes counts-before CMD, post-CMD and after PDT in the cases

conventional methods of endodontic instrumentation and irrigation are performed to the highest technical standards. ${ }^{1}$

In recent years, PDT has been employed to target microorganisms in root canals suggesting its usefulness as an adjunct to current endodontic disinfection techniques. However, most of the studies have been done in vitro ${ }^{7-23}$ and on permanent teeth and very few in vivo ${ }^{24,25}$ with only one study till date being done on deciduous teeth. ${ }^{26}$

In the present 'in vivo' study we used naturally infected teeth, as they contain a much broader spectrum of pathogens

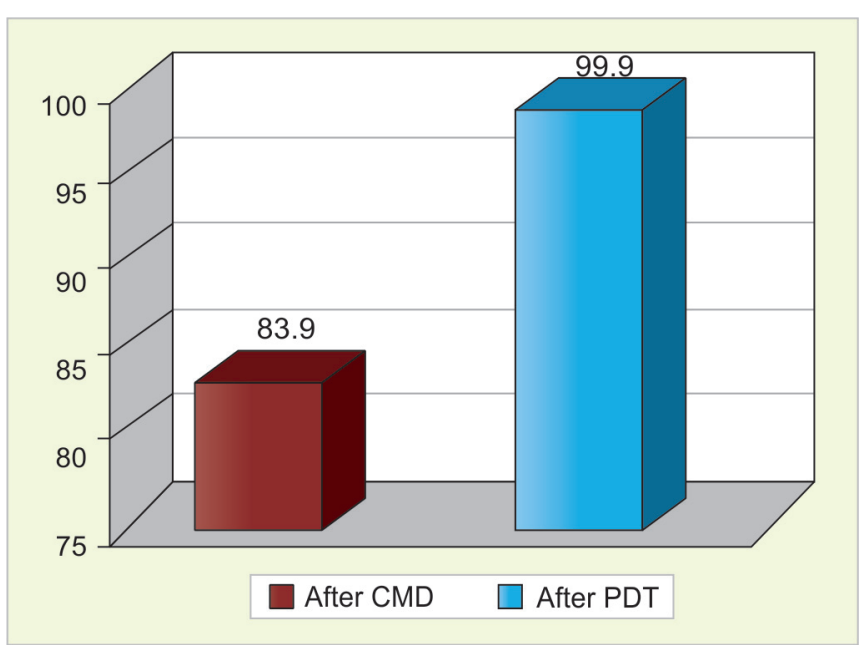

Graph 2: Mean percentage reduction in viable microbial countafter CMD and after PDT

with deeper penetration into the tubules compared to any 'in vitro' system.

The end outcome of any photodynamic intervention is dependent on many factors like the power density (energy fluence), exposure time, photosensitizer concentration, its absorption spectra and retentivity, optical properties of tissues, and the electromagnetic radiation intensity reaching the therapy site..$^{25,27-29}$ Though numerous dyes have been used for PDT, blue dyes have shown better results in reducing the bacterial and fungal cultures. ${ }^{30}$ 
MB was used as the photosensitizer in this study because of its superior hydrophilicity ${ }^{31}$ along with its low molecular weight and positive charge, which allows passage across the porin-protein channels in the outer membrane of Gram-negative bacteria. ${ }^{32} \mathrm{MB}$ whose intravenous administration is FDA approved, predominantly interacts with the anionic macromolecule lipopolysaccharide and results in the generation of dimers, ${ }^{32}$ which participate in the photosensitization process. ${ }^{32}$ We used a $660 \mathrm{~nm}$ laser wavelength since it came closest to the ideal wavelength of 665 which has been shown to have the best absorption as far as MB solution in PBS is concerned. ${ }^{7}$

The superior results obtained with regards to canal disinfection can be explained by understanding the effectives of PDT which is ultimately determined by the concentration of the photosensitizer. ${ }^{33}$

In a similar study, which used $25 \mu \mathrm{g} / \mathrm{ml} \mathrm{MB}$ dye in combination with a diode laser $\left(660 \mathrm{~nm}, 30 \mathrm{~J} / \mathrm{cm}^{2}\right.$ energy), an $80 \%$ reduction of the bacterial count was seen, ${ }^{17}$ whereas in the present study using the same diode laser $(660 \mathrm{~nm})$ at a much lower energy fluence of $8.6 \mathrm{~J} / \mathrm{cm}^{2}$, using the same photosensitizer MB dye but at a higher concentration of $50 \mu \mathrm{g} / \mathrm{ml}$ a total reduction of $99.9 \%$ in the total viable bacterial count was seen as studied by the microbial growth on culture plates showing complete absence of microbial colonies after PDT (Figs 3A to C).

In another study where MB was used at $(25 \mu \mathrm{g} / \mathrm{ml})$ for 5 minutes in combination with a laser of $665 \mathrm{~nm}$ and an energy fluence of $30 \mathrm{~J} / \mathrm{cm}^{2}$ resulted in complete elimination of all bacterial species with the exception of E. faecalis (53\% killing). ${ }^{33}$ The same concentration of MB in combination with laser at $222 \mathrm{~J} / \mathrm{cm}^{2}$ was able to eliminate $97 \%$ of E. faecalis. Hence, in the present study, MB was used at a higher concentration of $50 \mu \mathrm{g} / \mathrm{ml}$ so as to determine its efficacy in obtaining canal disinfection without having to increase the laser dose and was successfully proved so.

Thus, it can be stated that PDT as an adjunct to chemomechanical debridement produces greater disinfection of the necrotic deciduous root canals. The importance of PDT seems to be accentuated more in the field of pediatric dentistry, where the anatomical and physiological

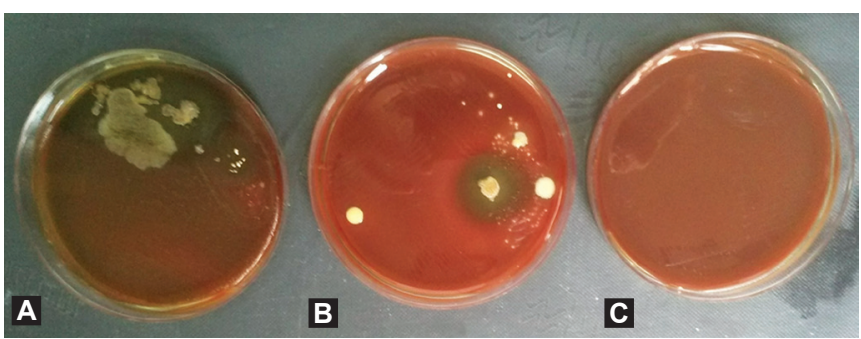

Figs 3 A to C: The microbiological growth on blood agar plates in one of our cases (A) before CMD, (B) after CMD, (C) after PDT characteristics of deciduous teeth limit the extent and effectiveness of CMD. However, further long-term studies are needed to study the effect of different laser systems at different power intensities and fluence levels so as to arrive at the most practical and feasible 'dose' for primary endodontic PDT.

\section{CONCLUSION}

The use of photosensitizing dye and a low-intensity laser appears to be a feasible, low-cost and nontraumatic alternative to complement classic endodontic therapy in the treatment of deciduous root canals.

\section{REFERENCES}

1. Siqueira JF Jr, Rocas IN, Paiva SS, Magalhaes KM, GuimaraesPinto T. Cultivable bacteria in infected root canals as identified by $16 \mathrm{~S}$ rRNA gene sequencing. Oral Microbiol Immunol 2007;22(4):266-271.

2. Pazelli LC, Freitas AC, Ito IY, Souza-Gugelmin MCM, Medeiros AS, Nelson-Filho P. Prevalence of microorganisms in root canals of human deciduous teeth with necrotic pulp and chronic periapical lesions. Pesqui Odontol Bras 2003;17(4):367-371.

3. Raab O. Uber die wirkung fluoreszierender stoffe auf infusorien. Z Biol 1900;39:524-546.

4. Westergren G, Krasse B. Evaluation of micromethod for determination of Streptococcus mutans and Lactobacillus infection. J Clin Microbiol 1978;7:82-83.

5. Sjogren U, Figdor D, Persson S, Sundqvist G. Influence of infection at the time of root filling on the outcome of endodontic treatment of teeth with apical periodontitis. Int Endod J 1997;30:297-306.

6. Nair PN, Sjogren U, Krey G, Kahnberg KE, Sundqvist G. Intraradicular bacteria and fungi in root-filled, asymptomatic human teeth with therapy-resistant periapical lesions: a longterm light and electron microscopic follow-up study. J Endod 1990;16:580-588.

7. Soukos NS, Chen PS, Morris JT, Ruggiero K, Abernethy AD, Som S, Foschi F, Doucette S, Bammann LL, Fontana CR, et al. Photodynamic therapy for endodontic disinfection. J Endod 2006;32:979-984.

8. Silbert T, Bird PS, Milburn GJ, Walsh L. Disinfection of root canals by laser dye photosensitization. J Dent Res 2000;79:569.

9. Seal GJ, Ng YL, Spratt D, Bhatti M, Gulabivala K. An in vitro comparison of the bactericidal efficacy of lethal photosensitization or sodium hyphochlorite irrigation on Streptococcus intermedius biofilms in root canals. Int Endod J 2002;35:268-274.

10. Garcez AS, Nunez SC, Lage-Marques JL, Jorge AO, Ribeiro MS. Efficiency of $\mathrm{NaOCl}$ and laser assisted photosensitization on the reduction of Enterococcus faecalis in vitro. Oral Surg Oral Med Oral Pathol Oral Radiol Endod 2006;102(4):e93-e98.

11. Williams JA, Pearson GJ, Colles MJ. Antibacterial action of photo activated disinfection (PA) used on endodontic bacteria in planktonic suspension and in artificial and human root canals. J Dent 2006;34:363-371.

12. Garcez AS, Ribeiro MS, Tegos GP, Nunez SC, Jorge AO, Hamblin MR. Antimicrobial photodynamic therapy combined with conventional endodontic treatment to eliminate root canal biofilm infection. Lasers Surg Med 2007;39(1):59-66. 
13. George S, Kishen A. Advanced noninvasive light-activated disinfection: assessment of cytotoxicity on fibroblast versus antimicrobial activity against Enterococcus faecalis. J Endod 2007;33(5):599-602.

14. George S, Kishen A. Photophysical, photochemical and photobiological characterization of methylene blue formulations for light-activated root canal disinfection. J Biomed Opt 2007;12(3):034029.

15. Foschi F, Fontana CR, Ruggiero K, Riahi R, Vera A, Doukas AG, Pagonis TC, Kent R, Stashenko PP, Soukos NS. Photodynamic inactivation of Enterococcus faecalis in dental root canals in vitro. Lasers Surg Med 2007;39(10):782-787.

16. Bergmans L, Moisiadis P, Huybrechts B, Van Meerbeek B, Quirynen M, Lambrechts P. Effect of photo-activated disinfection on endodontic pathogens ex vivo. Int Endod J 2008;41:227-239.

17. Fimple JL, Fontana CR, Foschi F, Ruggiero K, Song X, Pagonis TC, Tanner AC, Kent R, Doukas AG, Stashenko PP, et al. Photodynamic treatment of endodontic polymicrobial infection in vitro. J Endod 2008;34(6):728-734.

18. Fonseca MB, Junior PO, Pallota RC, Filho HF, Denardin OV, Rapoport A, Dedivitis RA, Veronezi JF, Genovese WJ, Ricardo AL. Photodynamic therapy for root canals infected with Enterococcus faecalis. Photomed Laser Surg 2008;26(3):209-213.

19. George S, Kishen A. Augmenting the antibiofilm efficacy of advanced noninvasive light activated disinfection with emulsified oxidizer and oxygen carrier. J Endod 2008;34(9):1119-1123.

20. George S, Kishen A. Influence of photosensitizer solvent on the mechanisms of photoactivated killing of Enterococcus faecalis. Photochem Photobiol 2008;84(3):734-740.

21. Lim Z, Cheng JL, Lim TW, Teo EG, Wong J, George S, Kishen A. Light activated disinfection: an alternative endodontic disinfection strategy. Aust Dent J 2009;54:108-114.

22. Souza LC, Brito PRR, Machado de Oliveira JC, Alves FRF, Moreira EJL, Sampaio-Filbo HR, Rocas IN, Siqueira JF Jr. Photodynamic therapy with two different photosensitizers as a supplement to instrumentation/irrigation procedures in promoting intracanal reduction of Enterococcus faecalis. J Endod 2010;36:292-296.

23. Pagonis TC, Chen J, Fontana CR, Devalapally H, Ruggiero K, Song X, Foschi F, Dunham J, Skobe Z, Yamazaki H, et al. Nanoparticle-based endodontic antimicrobial photodynamic therapy. J Endod 2010;36:322-328.

24. Bonsor SJ, Nichol R, Reid TM, Pearson GJ. An alternative regimen for root canal disinfection. Brit Dent J 2006;22:101-105.
25. Spikes JD, Jori G. Photodynamic therapy of tumours and other diseases using porphyrins. Lasers Med Sci 1987;2:3-15.

26. Pinheiro SL, Schenka AA, Neto AA, De Souza CP, Rodriguez HM, Ribeiro MC. Photodynamic therapy in endodontic treatment of deciduous teeth. Lasers in Med Science 2009;24(4):521-526.

27. Malik Z, Hanania J, NitzanY. Bactericidal effects of photo activated porphyrins - an alternative approach to antimicrobial drugs. J Photochem Photobiol B 1990;5:281-293.

28. Wilson M. Photolysis of oral bacteria and its potential use in the treatment of caries and periodontal disease. J Appl Bacterio 1993;75:299-309.

29. Zampieri MJP, Cogo JC, Genovese WJ, Barbosa AD. Photodynamic therapy in bacterias st mitis st sanguis in vitro. Rev Bras Implant 2003;9:16-17.

30. Shibli JA, Martins MC, Garcia VG, Marcantonio JRE. Tratamento de peri-implantite utilizando fotossensibilizacao: Resultados microbiologicos. Pesqui Odontol Bras 2001;15:127.

31. Wainwright M, Phoenix DA, Marland J, Wareing DR, Bolton FJ. A study of photobactericidal activity in the phenothiazinium series. FEMS Immunol Med Microbiol 1997;19:75-80.

32. Usacheva MN, Teichert MC, Biel MA. The interaction of lipopolysaccharides with phenothiazine dyes. Lasers Surg Med 2003;33:311-319.

33. Konopka K, Goslinski T. Photodynamic therapy in dentistry. J Dent Res 2007;86:694-707.

\section{ABOUT THE AUTHORS}

\section{AR Prabhakar (Corresponding Author)}

Professor and Head, Department of Pedodontics and Preventive Dentistry, Bapuji Dental College and Hospital, Davangere, Karnataka, India, Phone: 09449602506, e-mail: attiguppeprabhakar@gmail.com

\section{Chandrashekar Yavagal}

Reader, Department of Pedodontics and Preventive Dentistry, Bapuji Dental College and Hospital, Davangere, Karnataka, India

\section{Sonali Agarwal}

Postgraduate Student, Department of Pedodontics and Preventive Dentistry Bapuji Dental College and Hospital, Davangere, Karnataka, India

\section{N Basappa}

Professor, Department of Pedodontics and Preventive Dentistry, Bapuji Dental College and Hospital, Davangere, Karnataka, India 